\title{
TOMOS IN THE CONTEXT OF THE RUSSIA AND UKRAINE INFORMATION WAR
}

\section{GABOR Nataliya,}

PhD (Philology), Associate Professor, e-mail: nat.gabor@gmail.com,

\section{LAVRYSH Yuliana,}

PhD (Social Communications), Associate Professor, e-mail: yuliana.lavrysh@lnu.edu.ua,

Ivan Franko Lviv National University, Faculty of Journalism, 49 General Chuprynky St., Lviv, 79044, Ukraine.

After the Revolution of Dignity on Maydan Square in Kyiv in 2013-2014, Russian military aggression began, which was marked by the annexation of Crimea and the beginning of a full-fledged war in the eastern territories of Ukraine. On January 6, 2019, Ecumenical Patriarch Bartholomew signed the Tomos for the Orthodox Church of Ukraine, which testified to the independent vector of development undertaked by Ukrainian Orthodoxy, which has long been under pressure from the Moscow Patriarchate. This event caused a resonance in both Ukrainian and Russian media. The purpose of the study is to find out how the process of granting the Tomos turned into one of the aspects of the information war between Ukraine and Russia. The publication presents the content of Ukrainian and Russian web resources dedicated to this event and analyzes how the media event of receiving the Tomos by the Orthodox Church of Ukraine influenced the internal social dialogue in Ukraine, communication between Ukrainian and Russian Orthodoxy, and information confrontation between Russia and Ukraine.

Key words: Tomos, Constantinople, Orthodox Church of Ukraine, web space.

\section{ТОМОС У КОНТЕКСТІ ІНФОРМАЦІЙНОÏ ВІЙНИ МІЖ РОСІєЮ \\ ТА УКРАЇНОЮ}

Після Революиї Гідності на Майдані Незалежності у Києві у 2013-2014 роках розпочалася російська воєнна агресія, яка озналенувалася анексією Криму та початком повноцінної війни на східних територіях Украйни. 6 січня 2019 року Вселенський Патріарх Варфоломій підписав Томос для Православної Церкви Украӥни, чим засвідчив самостійний вектор розвитку украӥнського Православ'я, яке тривалий час перебувало під тиском Московського Патріархату. Ця подія викликала резонанс як в украӥнському, так і російському медіа-просторі. Мета дослідження-осмислити, як процес надання Томосу став одним із аспектів інформаційної війни між Україною та Росією. У публікацї представлено контент українських та російських веб-ресурсів, присвячених цій подї та проаналізовано, як медіа-подія отримання Томосу Православною Церквою Украӥни вплинула на внутрішньо суспільний діалог в Україні, комунікацію між украӥнським та російським Православ'ям, інформаційне протистояння між Росією та Украйною.

Ключові слова: Томос, Константинополь, Православна Церква України,веб-простір.

$\mathbf{I}_{\mathrm{t}}^{\mathrm{n}}$ ntroduction. Ukrainian society has confronted a challenge of Russia's massive attack on Ukraine's sovereignty, including annexation of Crimea and war in the east of Ukraine. All these events laid the foundation for rethinking and reformatting public opinion. After all, this entire time span, from the peaceful protest in Kyiv and the support of European integration to the war in eastern Ukraine, can be safely described as another milestone of national self-affirmation. On January 6, 2019, Bartholomew I, the Ecumenical Patriarch of Constantinople, signed the Tomos that granted autocephaly to the Orthodox Church of Ukraine, which changed the vector of both internal (interchurch within Ukraine) and external communication (at the level of the Orthodox Catholic (universal) Church). Not only did the Church play the role of a moral and spiritual center but it was also a pillar of independence and state integrity. And this was charac(c) Gabor N., Lavrysh Y., 2020 
teristic not only of Ukraine but also of other nations of the Slavic world. Establishment of Church autocephaly for many countries meant strengthening the state's foundation and independence. Although the Church in Ukraine is separated from the state, the issue of Ukrainian Orthodoxy is always considered to be equal to state independence, as the influence of the Russian Church in Ukraine is no less noticeable.

The struggle for the Local Orthodox Church in Ukraine actually permeated the entire period of Ukraine's independence. Russia, an official successor to the USS and bearer of the imperial tradition, not interested in the development of Ukraine in various aspects: political, social and also religious. When the war in eastern Ukraine started, the conceptual topoi in the Ukraine-Russia discourse were aggravated through the media by both sides. The process of creation of the Local Orthodox Church in Ukraine also turned into a discourse of Ukrainian-Russian information war. As of the end of 2018, there were more than 12,000 parishes of the Ukrainian Orthodox Church of the Moscow Patriarchate. Given Ukrainians' spiritual dimension and the high level of trust, the Church also became a mouthpiece for various ideological concepts, including Russian ones. That is why the topic we intend to describe is relevant and important not only for the religious environment of Ukraine but also for its self-affirmation in the foreign policy frame of reference. The analysis below addresses discourses related to agents representing different viewpoints on the events that make impact on Church life, and these discourses are examined in the context of the Russian-Ukrainian information war, which is part of hybrid war that Russia wages on Ukraine and the world.

The purpose and objectives of the study. The purpose of the study is to understand how the process of granting the Tomos became one of the aspects of the information war between Ukraine and Russia.

The defined goal is based on the following tasks: to analyze the content of the Ukrainian and Russian media on receiving the Tomos by the Orthodox Church of Ukraine, to present how the main messages of the messages represent the information confrontation between the states, to see the prospects for the development of information warfare.

In Ukrainian Journalism Studies, the importance of obtaining the Tomos not only for the establishment of the Orthodox Church of Ukraine but also for the development of the Ukrainian state was covered by researchers such as Alla Boiko, Andriy Yurash, Liudmyla Fylypovych, and Viktor Yelenskyi.

Research methods. The following methods were used during the study: comparative method (for comprehension of the communication messages of Russian and Ukrainian information resources on obtaining the Tomos), monitoring (selection and presentation of the key concepts of Russian-Ukrainian discourse on this event in the Ukrainian clerical environment), content analysis (taking into account authoritative Ukrainian secular mass media: Hromadske, Radio Svoboda, Ukrainska Pravda, BBC Ukraine, Ukrainian Week, Mirror of the Week, UNIAN, and secular media that write about religion such as the Religious Information Service of Ukraine, as well as Russian media such as RIA Novosti, Life.ru, and Patriarchia.ru, as well as Ukrainian media with a pro-Russian stance, i.e. ZIK, NewsOne, Strana.ua), and the method of observation.

Results and discussion. However, the internal Ukrainian socio-political factor undoubtedly influences Ukraine's status and situation in relation to global trends and discourses. In view of this, it is important that social institutions in society should be efficiently represented in online communication. Besides, the institution of the Church is an integral part of the development of socio-political relations, social problems, moral and spiritual values. The struggle for Ukrainian autocephaly was accompanied by information flows as media tools, no doubt, play a role no less important than organizational efforts and grassroots initiatives in the creation of civil society. After all, the period of the Tomos granting overlaps with the period following the Revolution of Dignity, during the Russian-Ukrainian war in eastern Ukraine, and, therefore, the 
period of reassessment of national values, conceptualization of the state's identity and, consequently, the public identity.

In January 2019, the Orthodox Church of Ukraine received a Tomos of Autocephaly granted by Patriarch Bartholomew of Constantinople. The Ukrainian Church's path to obtaining the Tomos can be divided into two periods: from the time when Ukraine gained its independence to the Revolution of Dignity (1991-2013) - it is during this period that the Patriarch of Constantinople first visited Ukraine, which took place under the presidency of Viktor Yushchenko; the second period started with the Maidan events, followed by annexation of Crimea, and presidential term of Petro Poroshenko till now (2013-2020).

Each of these stages was accompanied by a media campaign and positioning of different parties, which is described in detail in our report. The information campaign on the granting of the Tomos and the post-period of formation of the position of the Orthodox Church of Ukraine as a separate agent turned into a discussion platform in the framework of the information war between Ukraine and Russia, because adherents of the Russian Orthodox Church and believers of the Ukrainian Orthodox Church of the Moscow Patriarchate do not recognize the Tomos and consider the Church "noncanonical" due to the fact that not all the autocephalous Orthodox Churches recognized the OCU. At any rate, this is evidenced by the media materials that we examine in this article.

In January 2019, in Constantinople, the Orthodox Church of Ukraine was granted Tomos. The media campaign surrounding this event can be viewed as the optics to examine formation of the Church image in modern society, because this process is a longlasting one and marks all milestones of Ukrainian state's independence. From now on, the Ukrainian Church is a part of the diptych of fifteen autocephalous Orthodox Churches. The Ukrainian media have paid considerable attention to the granting of the Tomos to the Orthodox Church of Ukraine, starting in April 2018, when Petro Poroshenko brought a relevant appeal to the Ecumenical Patriarch up for a vote to Ukrainian MPs. Previously, within the time-frame when the issue was raised, information about the Local Orthodox Church was somewhat fragmented in the media. It was in April 2018 that targeted media monitoring of the processes of the Ukrainian Orthodox space began. Undoubtedly, the popularization of this topic has had both an intra-Church and a sociopolitical dimension, since in spring 2019 a presidential election campaign began in Ukraine. Kateryna Shchotkina, a journalist who covers religious topics, argues that the church autocephaly was a real trump card of President Petro Poroshenko's term1. On the other hand, according to other authors, the Tomos served as a cover for political campaigning, especially the Tomos Tour, that is, visits to Ukraine's key cities with a copy of the Tomos and clergy to celebrate the historic event. These trips ended with speeches by Petro Poroshenko in front of the city community [8].

The issue of creating the One Local Church within the Ukrainian inter-denominational space is not new. In our opinion, the discussion on the creation of a single Orthodox dimension began in the early 1990s, namely with Ukraine's independence. In 1992, Bishop Filaret (Denysenko) drifted away from the Russian Orthodox Church and established the Ukrainian Orthodox Church of the Kyiv Patriarchate, and in August 1989 another Orthodox branch, the Ukrainian Autocephalous Orthodox Church, began to form. Thus, since then, there have been three branches of Orthodoxy in Ukraine - the Ukrainian Autocephalous Orthodox Church (UAOC), the Ukrainian Orthodox Church of the Kyiv Patriarchate (UOC KP), and the Ukrainian Orthodox Church in unity with the Moscow Patriarchate (its legal name is UOC, but in order to emphasize its involvement with Moscow, the media refer to this denomination as the UOC (MP).

Regarding the unity of the churches of the Kyiv tradition, there have been several attempts to unite the successors of Prince Volodymyr's baptism. For example, in 2008 
President Viktor Yushchenko initiated a union of Ukrainian Orthodoxy through its subordination to Constantinople. There has also been an "inclusive model» of unity proposed by the Head of the UGCC, His Beatitude Lubomyr, which was vehemently rejected by the Orthodox Churches of Ukraine. At the heart of this model was the model of unity of the Churches, dating back to 988 , that is, to the adoption of the baptism of Kyevan Rus by Prince Volodymyr the Great. It meant involving not only the Orthodox denominations but also the Ukrainian Greek Catholic Church. After Viktor Yanukovych's victory in the presidential election, active attempts were made to overcome the intrachurch split through state pressure and revocation of the registration of the Ukrainian Orthodox Church of the Kyiv Patriarchate.

Given the proposed periodization, the media campaign on the Tomos granted to the Orthodox Church of Ukraine can be divided into two stages. On July 25, 2008, Patriarch Bartholomew paid his first official visit to Ukraine. The patriarch emphasized the importance of creating a single Orthodox space and of returning to the Mother Church. The Ukrainian Orthodox Church of the Kyiv Patriarchate and the Ukrainian Autocephalous Orthodox Church sought to unite and were willing to embrace the patronage of Constantinople. The Ukrainian media published less than favorable comments on the arrival of Patriarch Bartholomew from priests of the UOC. «Unofficially, this is a done deal: there are such arrangements, there is already a scheme for bringing, so to speak, the Kyiv Patriarchate and the UAOC under the jurisdiction of the Patriarchate of Constantinople», said Archimandrite Cyril (Hovorun) in his comments for Ukrayinska Pravda in 2008 [3]. Today, Father Cyril openly supports the OCU. However, it was but the first stage of a media campaign concerning the establishment of the Local Church in Ukraine and the prospects of receiving the Tomos. It is noteworthy that in 2018, Viktor Yushchenko spoke with Hromadske TV journalists about the events of 2008. The former President of Ukraine noted that the Tomos of Autocephaly could have been granted to the OCU ten years ago. During the visit of Patriarch Bartholomew to Ukraine in 2008, a scheme was prepared for obtaining autocephaly, according to which «every bishop of the Ukrainian Autocephalous Orthodox Church and the Ukrainian Orthodox Church of the Kyiv Patriarchate had to write a petition in the name of the Patriarch of Constantinople expressing their support and aspirations for the establishment of the Local Church" [16]. But, according to the former President, Patriarch Alexy II of the Russian Orthodox Church came to Kyiv and had a meeting with Patriarch Bartholomew, after which the latter rejected the idea of Tomos. Given these facts, we clearly see the geopolitical scale in discussing the issue of obtaining autocephaly by the Orthodox Church of Ukraine. This is particularly evident in the second period.

At the second stage, during the period of the Revolution of Dignity, especially after the Maidan massacre, Ukrainian society started generating slogans such as: "An independent state needs an independent Church». On February 22, 2014, the official website of the UOC KP published an appeal by the Holy Synod on the necessity to urgently overcome the split of the Orthodox Church in Ukraine. From August 29 to September 3, 2015, a Synaxis (assembly) of bishops of the Patriarchate of Constantinople was held at the Holy Trinity Church in the neighborhood of Katip of Constantinople (now Istanbul). One of the important issues was the unity of Ukrainian Orthodoxy. To solve the issue, His All-Holiness Ecumenical Patriarch Bartholomew met with hierarchs of the UOC of the USA and Canada, two of whom, namely Bishops Daniel Zelinsky and Hilarion Rudnyk, visited Ukraine, where they acted as mediators in the unification negotiations between the UAOC and the UOC KP. During these meetings, the diaspora hierarchs, among other things, expressed their opinion that the problem for the unity of Ukrainian Orthodoxy is that one of the branches of Orthodoxy in Ukraine is part of the Moscow Patriarchate. Therefore, one of the Orthodox denominations is canonical and the other two are not. During these meetings, a proposal was made that the unity of Ukrainian 
Orthodoxy could be achieved by bringing the Orthodox jurisdictions of Ukraine under the omophorion of the Ecumenical Patriarch. Back then, one could follow the process on the social media accounts of Archbishop of Chernihiv and Nizhyn Yevstratii (Zoria), Metropolitan of Lviv and Sokal Dimitri (Rudiuk), who represented the UOC KP (today the OCU), or Father Mykola Danylevych, who is an OCU priest. It was then that certain clergy groups were formed for the purpose of finding understanding between the UAOC, the UOC KP and the UOC. Therefore, in the Ukrainian media space, Maidan served as a catalyst for the creation of an autocephalous Local Church. At least, this topic was again covered in the media.

Oksana Horkusha, a religious studies scholar, noted that the Maidan gave impetus to the creation of not only the Local Church but also the Civil Church of Ukraine, where every layman and clergyman has a clear both spiritual and statesmanlike stance [6].

In 2016, the Pan-Orthodox Council was held on the island of Crete, which also represented the diversity of adherents of Ukrainian and Russian Orthodoxy. At the time, the Russian-Ukrainian war in the East of Ukraine had lasted for a year. Russia sought to reinforce its influence, including in the ecclesiastical issue. "The Ukrainian issue, the Ukrainian Church and its status turned into an apple of discord between Constantinople and Moscow», said religious studies expert Liudmyla Fylypovych. The Russian Orthodox Church, the Georgian Orthodox Church, and the Bulgarian Church did not participate in the Council. Ukrainian media were discussing Moscow's allies, and the Ukrainian parliament drew up an appeal to the Ecumenical Patriarch to grant autocephaly to the Orthodox Church. In the Russian media, the Council of the Orthodox Church was commented by Metropolitan Hilarion (Alfeyev), the Head of the ROC External Church Relations Department, who noted that the Local Church in Ukraine is a geopolitical project not only of Constantinople but also of the United States, as the United States allegedly finances the Ecumenical Patriarchate to weaken Russia [9]. Undoubtedly, the Pan-Orthodox Council of Crete found that Moscow was struggling with Constantinople for influence; in addition, the Orthodox Churches showed themselves as allies of one of the parties, as evidenced by clergy speeches during the Council [1].

In this second phase, it is important to note the period from April to December 2018, which was the final stage in obtaining autocephaly by the Orthodox Church of Ukraine. On April 17, 2018, at an emergency meeting with the heads of factions, the then-President Petro Poroshenko asked the Verkhovna Rada to support the appeal of «President and Church Hierarchs to the Ecumenical Patriarch» to grant the Tomos. Meanwhile, the media were publishing comments from the UOC hierarchs. "We have not heard any new statements from Patriarch Bartholomew. His stance has not changed. The Ecumenical Patriarchate considers the Ukrainian Orthodox Church headed today by His Beatitude Metropolitan Onufriy to be the only legitimate church in Ukraine», said Bishop Clement of Irpin (Vecheria), the official spokesman of the UOC [14]. The traditional and new media published photos of the UOC delegation to Constantinople regarding an unequivocal refusal to grant the Tomos. At the end of July 2018, Patriarch Cyril made an official visit to the Ecumenical Patriarchate. The new media, in particular, produce numerous humorous memes about the reception of the Russian Patriarch in Constantinople. It was alleged that Cyril brought money from Moscow to bribe Patriarch Bartholomew. However, the process of granting the Tomos was irreversible. In the fall of 2018, Constantinople appointed two exarchs in Ukraine - Bishop Daniel (Zelinsky) and Hilarion (Rudnik) to prepare for the Unification Council. Seeing that the process was irreversible, on September 14, 2018, the Synod of the Russian Orthodox Church decided to stop mentioning the Patriarch of Constantinople, Bartholomew I, in their prayers. This decision was made following the extraordinary meeting of the ROC Synod. «The Synod has decided to stop mentioning the Patriarch of Constantinople during the liturgy of the Russian Orthodox Church», Metropolitan Hilarion of Volokolamsk told reporters 
(according to the Russian TASS news agency) [2]. At the same time, this decision did not mean breaking the Eucharistic communion between Moscow and Phanar. On December 15, 2018, the Sofia Cathedral hosted the Unification Council, where Epiphanius (Dumenko) was elected Metropolitan of Kyiv and all Ukraine, and the branches of the UOC KP and UAOC merged into a unified OCU.

The media campaign regarding the granting of the Tomos to the OCU can be described as polarized, apart from the fact that the Ukrainian media clearly supported this step of support and dialogue between the state and the Church, expressing hope for the future, and focusing on the young age of Metropolitan Epiphanius, the UOC MP developed their strategy voiced on NewsOne or 112 Ukraine TV channels, saying that there was already a canonical Church in Ukraine, no need for one more; monasteries and churches after the granting of the Tomos would be taken by force; they were not the ROC in Ukraine (the Ukrainian Parliament voted to rename the UOC to ROCinU) since our legal name is the UOC; ROC is the most powerful of the Local Churches, its withdrawal will result in a universal schism of the Orthodox world.

At the time of the Tomos granting, the Russian media seemed to fall into a kind of an information panic. For example, the most popular Russian media published articles with the following headlines: «Poroshenko Stole Christmas: Schismatics Got Tomos» [11], «Tomos on Autocephaly Signed to Ukrainian Songs and Banderite Slogans», "Phanar's 'Gifts'. What Can Judas' Tomos Change?» [4]. In their materials, Russian journalists continued to use verbal markers such as: «schismatics», «non-canonical», «Banderites». These labels, in our view, further exacerbated the information confrontation in particular regarding the church issue. The Ukrainian information space also abounded in research on the media campaign around the Tomos granting to the Orthodox Church of Ukraine. Ukrainian journalists' monitoring of the topic of the Tomos granting to the Orthodox Church of Ukraine helped detect the key messages of pro-Russian resources. For instance, the Media Detector website, specializing in media criticism, published their article «Tomos to Bar out from EU», claiming that Tomos poses a threat to EU accession, because Petro Poroshenko's risky undertaking is regarded differently there. Communities of the Ukrainian Orthodox Church of the Moscow Patriarchate reported a threat of their seizure by the Orthodox Church of Ukraine to the OSCE.

In October 2019, Internews Ukraine jointly with the Media Diversity Institute (Armenia), the Journalism Resource Center (Georgia), and the Independent Journalism Center (Moldova) monitored the media in their countries for the presence of Russian propaganda concerning recognition of the Ukrainian Local Church 12. In Ukraine, major TV channels such as $1+1$ and 112 Ukraine were studied, as well as the online resources Ukrayinska Pravda and Strana, which are among the top 10 most visited news sites according to the Internet Association of Ukraine. According to the study, $86 \%$ of news about autocephaly on 112 Ukraine and $98 \%$ on Ukrayinska Pravda was neutral. Instead, on $1+1,31 \%$ of mentions were positive or very positive. At the same time, Strana, an online resource with a clear pro-Russian stance, quite often published reports including narratives of Russian propaganda, accounting for 38\% . In Georgia, the pro-government TV channel Imedi TV, the opposition channel Rustavi-2, as well as the Ipress.ge and netgazeti.ge sites were studied. One negative report on the Ukrainian autocephaly was found on Imedi TV and netgazeti.ge, while the other ones were neutral or positive. According to the researchers, the content of the media included slogans of Russian propaganda but they were counterbalanced by opposing views. Armenian analysts monitored Channel 1 (State Television of Armenia) and Kentron TV, as well as the online media news.am and lragir.am. Experts noted that attention to the Ukrainian Church issue was minimal, mostly the media cited official comments from the Russian Orthodox Church. The three Moldovan media under study - Publika TV, NTV Moldova and jurnal. md - disseminated very short reports, usually with reference to one source [12]. 
Based on the study, we can conclude that the issue of the Ukrainian Local Church within the framework of the Ukrainian-Russian information war acquired a political context. As we noted above, the Orthodox world was divided into supporters of one of the parties, those who favor Ukraine's standing and those who support Russia's position. Finally, the message of the Pan-Orthodox Council regarding the division of influence between the autocephalies in Russia and Constantinople was confirmed.

After the Tomos granting, nearly 600 parishes of the Ukrainian Orthodox Church of the Moscow Patriarchate came over to the Orthodox Church of Ukraine [7]. However, while the OCU referred to it as transition, the UOC described the process as seizure of parishes. It was especially evident in the Vinnytsia region, where the local Bishop Symeon of Vinnytsia and Bar was one of the two bishops of the UOC who participated in the OCU Unification Council in December 2018. After Bishop Symeon's excommunication, Varsonofiy was appointed Bishop of Vinnytsia and Bar [15] . However, parishes kept coming over to the OCU, although now in 2020 the cases of transition have become less frequent.

Following the official granting of the Tomos in January and the enthronement of Metropolitan Epiphanius in February 2019, internal conflicts within the OCU began. In May 2019, Honorary Patriarch Filaret convened a press conference accusing former President Petro Poroshenko and Metropolitan Epiphanius of treachery, since the granting of the Tomos was supposed to result in recognition of the UOC KP rather than creation of the OCU, and Patriarch Filaret was supposed to become its Primate. Even though in October 2018, on the eve of the Unification Council, Constantinople sent a letter specifying that one of the requirements of the Patriarchate was that Patriarch Filaret should not be nominated for primacy. That is why the media campaign on granting the Tomos shifted to the intra-church level. Bishop Filaret retained the status of Honorary Patriarch, but he does not participate in the Synodal Meetings of the OCU and does not maintain contacts with the bishops of the Church. In the media, the Honorary Patriarch emphasizes that the Tomos contains certain inaccuracies with which he disagrees, argues that the purpose of his life was to have the Patriarchate established, and mentions his passive communication with His Beatitude Epiphanius. It is noteworthy that interviews with the Honorary Patriarch are broadcast on ZIK, a TV channel with a clear pro-Russian editorial policy. This example demonstrates that information contradictions between Russia and Ukraine focus on internal conflicts rather than on external information messages of Russian TV channels. However, the OCU episcopate did not support the idea of the Honorary Patriarch, remaining subordinate to His Beatitude Epiphanius.

Another aspect attracting the attention of Russian or pro-Russian media is recognition of the OCU by other autocephalous Orthodox Churches. It is worth reminding that the Ukrainian Church has been recognized by the Greek Orthodox Church, the Patriarchate of Alexandria and the Romanian Orthodox Church. The Metropolitan of Kyiv and All Ukraine noted that in 2020, in addition to the Romanian Church, the OCU would be recognized by the Bulgarian Orthodox Church, the Cyprus Orthodox Church, and the Georgian Orthodox Church [10].

\section{Conclusions and prospects.}

First, the information campaign on granting the Tomos to the Orthodox Church of Ukraine was under way not only in 2018-2019 but from the moment of proclamation of Ukraine's independence, since church independence is the foundation of statehood.

Secondly, within the framework of the information campaign under study, we see a clear contradiction between the Russian Orthodox Church and the Orthodox Church of Ukraine, which is evidenced by the content of both Russian and Ukrainian media with a clear pro-Russian stance. And this, in turn, proves Russia's desire to triumph on different fronts. The propaganda campaign aimed at compromising Ukraine's independent church has been part of Russia's war against Ukrainian state and its sovereignty; 
Thirdly, the information contradiction in the focus of the church-related content between Russia and Ukraine reveals both external but internal conflicts, which are the focus of media attention, in particular between the clergy of the Orthodox Church of Ukraine and the Ukrainian Orthodox Church in unity with the Moscow Patriarchate. Internal disagreement between Orthodox Churches destabilizes the dialogue and undermines understanding in the Ukrainian religious space.

Fourthly, Russia's information policy also focuses on other autocephalous Churches that have not yet recognized the Orthodox Church of Ukraine. This is why the process of OCU recognition is so lengthy. Its futher results and final outcome depends on quality of the campaign at both national and international level, public dialogue, how the media will convey the importance of an independent Orthodox Church of Ukraine.

Prospects for further development of the topic are how the information campaign on the recognition of the PCU among other Local Orthodox Churches will develop. This is important not only for the Ukrainian church world, but also to prove Ukraine's full independence from Russia.

1. Chervonenko V. Will Ukraine benefit from the Moscow-Constantinople dispute? URL: https://www.bbc.com/ukrainian/politics/2016/06/160617_church_orthodox_synod_vc.html (accessed 04 November 2020).

2. Cyril stops mentioning Patriarch Bartholomew during liturgy - URL: https://www.pravda. com.ua/news/2018/09/14/7192126/ (accessed 04 November 2020).

3. Ecumenical Patriarch for unification of Ukrainian churches - URL: https://www. radiosvoboda.org/a/1186328.html (accessed 01 November 2020).

4. Gifts of Phanar. What Can Judas' Tomos Change? URL: https://life.ru/p/1183443 (accessed 04 November 2020).

5. Honorary Patriarch Filaret. Interview with Lytvynenko. 10.01.20. URL: https://zik.ua/ tv/video/233393 (accessed 02 November 2020).

6. Horkusha O., Fylypovych L. Born on the Maidan - Civil Church of Ukraine. URL: https:// risu.org.ua/ua/index/studios/studies_of_religions/56419/(accessed 04 November 2020).

7. How Many UOC (MP) Parishes Came over to UOC: Map. URL: https://fakty.com.ua/ua/ ukraine/20200106-skilky-parafij-rpts-perejshlo-do-ptsu-karta/ (accessed 05 November 2020).

8. Journalists tried to calculate the cost of Poroshenko's Tomos Tour. URL: https://www.unian. ua/politics/10416972-zhurnalisti-sprobuvali-pidrahuvati-vartist-tomos-turu-poroshenka-video. htm (accessed 04 November 2020).

9. Metropolitan Hilarion of Volokolamsk: „There is no authority over the Local Orthodox Church except God». URL: http://www.patriarchia.ru/db/text/5330417.html (accessed 02 November 2020).

10. Next Year Another 4 Churches Might Recognize OCU - Epiphanius. URL: https://www. pravda.com.ua/news/2020/01/7/7236753/ (accessed 01 November 2020).

11. Poroshenko stole Christmas: schismatics got Tomos. - URL: https://ria. $\mathrm{ru} / 20190105 / 1549057373 . \mathrm{html}$ (accessed 04 November 2020).

12. Tomos and Propaganda: Kremlin Messages in Media URL: https://tyzhden.ua/ Society/236031 (accessed 04 November 2020).

13. Tomos is the trump card of the presidential campaign - columnist. URL: https://dt.ua/ POLITICS/tomos-ye-kozirem-prezidentskoyi-kampaniyi-oglyadach-300104_html (accessed 04 November 2020).

14. UOC (MP): there is no reason for the Ecumenical Patriarch to recognize another Ukrainian Church. URL: https://www.radiosvoboda.org/a/news/29172964.html (accessed 05 November 2020).

15. UOC Transitions in Vinnytsia Region: Blackmail, Violence and Empty Churches of Epiphanius - interview with Metropolitan Varsonofiy. URL: https://law.church.ua/2020/02/18/ perevodi-v-pcu-na-vinnichini-shantazh-nasilstvo-i-porozhni-xrami-epifaniya-intervyumitropolita-varsonofiya/ (accessed 01 November 2020).

16. Yushchenko: «In 2008, the granting of Tomos was prevented by the Patriarch of the ROC Alexy II». URL: https://hromadske.ua/posts/yushenko-u-2008-roci-nadannyu-tomosu-zavadivpatriarh-rpc-aleksij-ii.htm. (accessed 04 November 2020). 


\section{ТОМОС У КОНТЕКСТІ ІНФОРМАЦІЙНОЇ ВІЙНИ МІЖ РОСІЄЮ ТА УКРАÏНОЮ}

Габор Наталія, канд. філол. наук, доцент, е-mail: nat.gabor@gmail.com, ORCID - https://orcid.org/0000-0001-6306-8326,

Лавриш Юліана, канд. наук із соц. комунік., доцент, yuliana.lavrysh@lnu.edu.ua,

ORCID - https://orcid.org/0000-0002-5205-9309,

Львівський національний університет імені Івана Франка, факультет журналістики, вул. Генерала Чупринки, 49, м. Львів, 79044, Україна.

Вступ. 6 січня 2019 року Православна Церква України отримала Томос про автокефалію від Вселенського Патріарха Варфоломія, що змінило вектор як внутрішньої - міжцерковної в Україні, так і зовнішньої комунікації - на рівні вселенського Православ'я. Творення церковної автокефалії для багатьох країн означало зміцнення державницького стержня і самостійності.

Актуальність і мета. Тема дослідження важлива саме у фокусі медіа-простору, оскільки між Україною та Росією, окрім війни на Сході, маємо інформаційне протистояння, а також помітну протидію між українським та російським Православ'ям. Мета публікації - осмислити, як сам факт надання Томосу вплинули на контент українських та російських медіа; як це інформаційне протистояння впливає на комунікацію між двома державами.

Методологія. У публікації застосовуємо такі методи: порівняльний (аналіз комунікаційних повідомлень російських та українських ресурсів щодо отримання Томосу), моніторинг (представлення ключових концептів російсько-українського медіадискурсу щодо цієї події в українському церковному середовищі), аналіз контенту (на основі аналізу медіаресурсів), а також метод спостереження.

Результати. У межах дослідження проаналізовано контент українських та російських, проросійськи налаштованих ЗМК щодо надання Томосу Православній Церкві України. Виявлено, що пропагандистська кампанія, спрямована на компрометацію незалежної української Церкви, була частиною війни Росії проти української держави та їі суверенітету. Також представлено, як розвиватиметься інформаційна кампанія щодо визнання ПЦУ серед інших Помісних Православних Церков.

Висновки. У результаті дослідження виявлено, що інформаційна кампанія щодо надання Томосу Православній Церкві України тривала не лише у 2018-2019 роках, але 3 моменту проголошення незалежності України, оскільки церковна незалежність є основою державності. По-друге, в рамках досліджуваної інформаційної кампанії ми бачимо явне протиріччя між Російською Православною Церквою та Православною церквою України, про що свідчить контент як російських, так і українських ЗМІ з чіткою проросійською позицією. А це, своєю чергою, доводить бажання Росії тріумфувати на різних фронтах. По-трете, інформаційне протиріччя у фокусі церковного змісту між Росією та Україною виявляє як зовнішні, так і внутрішні конфлікти, які є предметом уваги ЗМІ, зокрема між духовенством Православної Церкви України та Українською Православною Церквою в єдності з Московським патріархатом. Внутрішня незгода між православними церквами дестабілізує діалог та підриває взаєморозуміння в українському релігійному просторі. По-четверте, інформаційна політика Росії також зосереджена на інших автокефальних Церквах, які ще не визнали Православну Церкву України.

Ключові слова: Томос, Константинополь, Православна Церква Украӥни, вебпростір. 